\title{
INSTALLATION OF THE TEMPLE TABLET, JUNE 17, 1913.
}

ADDRESS BY HON. THOMAS HEDGE.

I thank you for this privilege of joining you while you are taking thought of yesterday, seeking to keep the past secure, recalling its lessons of soberness and steadiness for today and of illuminating guidance for tomorrow.

A frequent mandate of our most ancient and authentic book of law is to remember. As a sound memory is a humanly prescribed requisite for a last will, a sound and active memory is a divinely ordained prerequisite for the informed, instructed and benevolent will which insures right conduct and develops pure character.

We and those who are to come owe and are to owe a great debt to Mr. Edward Temple for providing in the Historical Department of Iowa a memorial of a group of pioneers, which not only shall perpetuate for those who knew them delightful memories of their personal traits, their familiar conversation, and their habits of life, but also, arresting the attention of another generation who knew them not, shall - excite curiosity, stimulate the study of the times and conditions in which they lived and the searching out of the qualities of mind and heart, by the exercise of which this commonwealth of Iowa, their heritage, was founded and builded and handed down to them "a goodly heritage."

Those conditions were strange but these were not strange men. If they had been there might be no lesson or inspiration for us in their story. They might have furnished no pattern or compelling example for us common men.

Because they were like ourselves, of like passions and limitations and "often infirmities" that story of adventurous enterprise, of hardness endured, of importunate energy, of difficulties overcome, of faith, of patience, of public spirit 
and neighborly kindness may not only justify our pride in our origin, but also quicken our sense of our own responsibility and impart to us sane notions of private conduct and of civil duty.

While these seven men were all native Americans their places of nativity were widely separate. Reckoning the ways and means of travel then, they were as remote from one another as Des Moines is today from Jerusalem-Jerusalem old or new.

The senior of them all, George Temple, or Major Temple as he was always addressed or spoken of, was born in Westmoreland, New Hampshire, in 1804 and was thirty-two years old when he came to Burlington, then in Wisconsin Territory. Levi Hager, whose counterfeit presentment you have not been able to obtain, was born in Hagerstown, Maryland, and came to Burlington in 1837. All the others were at least ten years younger. Anthony Wayne Carpenter, named for his father's famous friend, born in Lancaster County, Penn., was twentythree and William B. Remey, born in Kentucky, was twentytwo when they landed at Burlington in 1837. Bernhart Henn was born in Cherry Valley, New York, a few miles from the home of James Fenimore Cooper, birthplace of the Indian of romance, and caught his first sight of Iowa Indians when, a boy of eighteen, he landed at Burlington in 1838 .

William F. Coolbaugh from Pike County, Penn., came later in 1842 at the age of twenty-one years and William Salter, a native of Brooklyn, New York, came in 1843 at the age of twenty-two years.

If time served it would be pleasant to attend in particular detail to the personal characteristies of these interesting men, their ways of life, the vicissitudes of their fortune, their fortitude under disappointment and failure, their moderation in success. They were as various in their personalities as seven North Americans well could be; so various that they might have seemed the epitome of all the stalwart and dominant races of mankind. But whatever this diversity of accident and external they were all true men, men of force and dignity, 
who won and held the friendship of each other and the esteem and confidence of all their neighbors in the new community.

It is pleasant to remember the urbane and handsome Major Temple, in manner and attire ever indicating his real nature as "a gentleman of the old school ;" the busy and ubiquitous Levi Hager from Hagerstown, whose every waking hour might have disproved Robert Ingersoll's libel of inertness on the native Marylander; the attractive and engaging ways of Anthony Carpenter whose sterling integrity and manifest human kindness secured his wide and lasting influence among all our people; the calm and genial presence, "the good gray head that all men knew" of Major Remey; that embodiment of energy and initiative, William F. Coolbaugh, our great merchant, an effective public speaker, who became our leading banker and then the first financial authority in Chicago.

It was not my privilege to know Mr. Bernhart Henn, but I have heard and read enough of him to count him an equal in that noble brotherhood and to presume that his employment in the land sales at Burlington in November, 1838, was one of his delightful memories.

Some of you may not know that every one who entered and occupied land in southeastern Iowa (then Michigan and Wisconsin Territory) from June 1, 1833, until November, 1838 , did so in disregard of written law, that he was a trespasser, as the strenuous one might say "a malefactor". March 3,1807 , Congress passed and President Jefferson approved an act providing that any person who should thus enter public lands and make any claim to any part thereof and attempt to define the limits of the land thus claimed by marking of trees or otherwise, unless thereto duly authorized by law should forfeit his right, title or elaim of whatsoever nature to said land, and that it would be lawful for the President to remove him therefrom at his discretion, ete. A láw beautifully adapted to the conservation of our natural resources in its prohibition of their discovery, also a warning as apt and effectual as might have been a written notice to the rain to keep off the grass. Later, Congress perceiving that the rain continued to fall, or to drop the figure, that free Americans were 
.going in increasing numbers whithersoever they listed on the public lands and were staking out claims thereon, and perhaps catching a glimmer of the principle that government, like the Sabbath, was made for man and not man for the government, enacted laws recognizing preemption rights in certain parts of the west and southwest, but none of these laws applied in terms to our neighborhood. So while our settlers held on their uncharted and unchartered course, this condition gave rise to general anxiety, to doubts, to controversies and to law suits. Three cases may be found in our Morris' Reports in which the defense is the alleged invalidity of a transfer of a settler's claim as a consideration of the promise to pay for it. The case of Hill against Smith tells the whole story. Judge Charles Mason's statement of the facts with his reasons for his judgment (sustaining the note) make what Horace Greeley would call mighty interesting reading, not only for lawyers but for any one desirous of learning through how great and how multifarious tribulation our fathers entered into this kingdom.

Finally the act of June 22, 1838, recognized, with conditions, preemption rights in Iowa. Land offices were established at Dubuque and Burlington. Gen. Augustus Caesar Dodge was made Register of the Land Office at Burlington and sales were duly ordered. Bernhart Henn was appointed crier at the sales. Of course everybody was on hand. Two thousand people they say were lodged or encamped.in and about Burlington, many sober and all in sober earnest. " "To establish justice, to promote the general welfare, and to provide for the common defense," claim clubs had been organized in every township. Each settler's claim with his name inscribed thereon was platted, and this plat thus inscribed placed in the hands of the able-bodied young settler who had been agreed upon as bidder for all concerned.

So all things had been prepared "decently and in order." At the sale "a decent respect to the opinions of mankind" (that mankind carrying big sticks) seems to have repressed ardor of competition for there was only one bid for each parcel of land. When young Bernhart cried "sold" in response to this solitary but unanimous bid, he seemed the herald of 
repose. This magic word removed the trespasser's transgression from him and changed the Stars and Stripes from a portent of eviction to a promise of protection.

Some twelve or fifteen years later Mr. Henn was our representative in congress but there is no record that any prophetic sense of a Sherman law ever stirred him to move for an annulment of his sales because of conspiracy or wicked combination or other rudimental methods of our rude forefathers.

In 1843 the American Home Missionary Society sent hither eleven young Christian ministers named in our annals "The Iowa Band" or "The Andover Band". The youngest of these was William. Salter, who first crossed the river at Burlington, November 10, 1843. His first allotted field was Maquoketa and the region round about. His colleague, Horace Hutchinson, assigned to Burlington, died in 1846, and in April of that year began William Salter's ministry, in the Congregational church of Burlington, which was vouchsafed to be continued for sixty-five years. He followed his Master never afar off, so seeing and doing his will in "the daily round, the common task," that his example came to be our approved exposition of the Sermon on the Mount. His simple way, his easy dignity, his enlightened sympathy, his plain unbounded charity for all sorts and conditions of men, drew all men unto him. Men of whatever belief or of whatever unbelief believed in him.

Persuaded that memory is a divine gift, its exercise a trust to be fulfilled, to his latest days he busied himself in the study and preservation of the annals of the past. On the day he became eighty-three years old he gave us "Iowa, the First Free State in the Louisiana Purchase", as thirty years before he had given us in his "Life of James W. Grimes", an invaluable record of the beginnings in Iowa and of her advance to prosperity and power.

But it is needless to dwell upon this individual history. The fact that George Temple and Levi Hager and Anthony Carpenter were mayors of Burlington and Major Temple the Speaker of our Towa House of Representatives; that Major Remey was our recorder and county treasurer for many 
years,- - has its best significance as evidence of the good sense of their neighbors and of the high character they demanded in the public service.

These men are best remembered not as exceptional men but as representatives of an exceptional class of men, for, as it seems to me, the men and women who entered and possessed our southeastern neighborhood in the territorial days from June, 1833, to December, 1846, were, taken as a whole, of that fine sort which might justify the ancient doctrine of election so far as it may be applicable to the world that now is.

It is worth noting that as a rule they did not come as colonists. The village of Denmark in Lee county, settled in 1838 by a group of families from New Hampshire is the only exception that I now call to mind. They came independently, each, as he would have described it, on his own hook. They were not Pilgrim Fathers seeking religious freedom. Whatever religion they were endowed with had had ample room for exercise at home. Nor were they Argonauts exploring for a golden fleece. They were simply the young, healthy, saneminded, venturesome sons and daughters of well-doing and well-to-do families of New England, New York, Pennsylvania, Virginia, North Carolina and Kentucky, who came hither to find among the wooded hills on the further side of the great river, on the silent, lonesome prairie, stretching so vastly toward the setting sun, work places and dwelling places. They came to make their way, to earn their living, to establish homes by the exercise of the homely virtues.

Not "the roll of the stirring drum", nor the "trumpet that sings of fame," but the axe ringing in the timber first sounded the advance of our vanguard of civilization.

We cannot claim that they were all in danger of being translated; then as now, no man could become a saint who was not capable of being a sinner. We cannot deny that here and there and now and then they were burdened by the idle, distressed by the vicious and infested by the common varieties of inconvenient citizens, enough to try the strength of their manhood and the grace of their womanhood, but we are thank- 
ful to remember that that strength and that grace were sufficient for the day.

I am not prepared to admit that I am misled by the enchantment that distance lends in my view of our territorial age as our golden age: Of course I do not mean in its material and temporal aspect,' but only that it was the age in which the conditions and exactions of daily life, calling into constant action even the reserve forces of mind and heart, brought forth the finest qualities of manhood and womanhood; to a high degree the strength and beauty of human character. Earning a living they entered into life.

Theirs was a community separate and sequestered, whose connection and cominunication with the great body of their own race was unfrequent, intermittent and precarious. They were a long way from home. For them the sun rose in a wilderness and set in a desert, for that part of Illinois from which the" rising morning awakened their "Flint Hills" was yet a solitary plain girded by the forest primeval, and the zig-zag rails that outlined the limit of the white man's progress were within the sweep of one's evening horizon, a single day's wagon journey from the bank of the Mississippi.

That river was "their way of necessity" to the outer and the older world. Whenever the smoke of a coming steamboat was descried over the southeastern bluff, almost the entire population hurried to the landing place, eager for the sight of new faces, or of old, familiar faces, for supplies, for newspapers and for letters. To get a letter was an event, for the letter was a composition of study, of deliberation, full of vital substance. There were letter writers in those days.

There was little of luxury or of elegance in their belongings. If of different degrees of origin as society was measured at their birthplaces, all were of one social order here. Hospitality was universal, a blessing and a need to the giver as to the receiver. While the habit of overcoming difficulties which the struggles of their daily life imposed upon them had bred in them a fine and constant self-reliance, they recognized and valued their mutual dependence; the common interest bound 
them. Bringing with them a diversity of experience, of opinion, of prejudice and of manners from their widely separated eastern homes, they found something to compare, to exchange and to learn from one another. There was the charm of novelty in their conversation. They enjoyed the great advantage of hobnobbing with those who saw things differently, and in their intercourse, at once becoming close and intimate, these original provincials instructed, educated, enlarged and Americanized each other, discovered their real kinship and common. likeness, found that their first unlikeness had been only. external and adventitious, never of the substance or of the spirit.

The transitory nature of their sectional prejudices, is illustrated if not proved by certain transactions deemed important in thoșe simple days:

Major Temple of New Hampshire married a daughter of Old Virginia, Sarah Forrest Deaton of Salem. Young Mr. Remey of Kentucky won a girl born in Vermont, a lineal descendant of John Howland of the "Mayflower", and William F. Coolbaugh of Pennsylvania surrendered to a Kentucky maiden. I need only say further that these unions were perpetual, ending only when death did them part as was the fashion of the pioneers. It could hardly have been otherwise for the pioneer wife and mother was in this image and after this likeness :

"The heart of her husband doth safely trust in her. She will do him good and not evil all the days of her life.

She seeketh wool, and flax, and worketh willingly with her hands.

She layeth her hands to the spindle, and her hands hold the distaff.

She stretcheth out her hand to the poor; yea, she reacheth forth her hands to the needy.

She openeth her mouth with wisdom; and in her tongue is the law of kindness.

She looketh well to the ways of her household, and eateth not the bread of idleness." 
A queen was she in the cabin of the pioneer as she had been a queen in the tents of Israel three thousand years ago; as her daughter is to be a queen encompassed by the love and loyalty and reverence of all men who honor the home as the inner sanctuary of the human soul, its hearthstone as the real foundation of our social order and of our civil liberty, until she herself shall fling away her seepter.

It seems a far cry from the radiator, whose canned heat may sometimes warm but never cheers or inebriates, back to the roaring, leaping hickory fire, lighted by the tinder and flint and steel, whose rioting flames "shooting sparkles out" kindled happy thoughts and bright fancies and fond recollections and new hope in the souls of our toil-worn forefathers. It seems ages past, counting by events and changes, when the puncheon floor was supplanted by the rough-sawn oaken boards and bricks and mortar began to supersede the log walls and riven roofs of the first cabins; when the great rafts of pine from the Wisconsin woods, with their lusty turbulent crews, first vexed the shining surface of our river. An ancient day it was when the hour for evening meetings was fixed at early candle light and the luxuriously-minded opulent lugged their little foot stoves to the place of worship; when the spinning wheel hummed in every dwelling and yoked oxen dragged the plow through every clearing as they had dragged hither over the long and difficult way our "peculiar ship of state", the prairie schooner, with its cargo of reinforcements for the conquest of the land; a dim past wherein men had not yet begun to dream that the earth shaking lightning might be the revealing of a force given to be harnessed and controlled for their common uses.

They were truly primitive times. They were not always hurried in those days. They sometimes had time to think and to think matters of thought out. Books were few, but "famed books", "read, .marked and inwardly digested".

The Bible was still regarded as the authentic body of rules for right living, and also searched and studied as the crown, the consummation and the preservative of literature. Even lawyers could cite its proverbs, its parables, its phrases to 
illustrate their points and their juries and judges were competent to apprehend them. Law books, too, were few in that golden age, and so the lawyer had to learn to use his mind, to train his mental vision in searching out the intrinsic reasonableness of his proposition, the self-evident truth of his postulate, that, seeing it clearly he might state it plainly, for self-evident truths are not always or often apparent to the cursory or squandering glance. They hold within themselves their own demonstration like the problem in geometry; they shine by their own light like the fixed star, but only the open and attentive mind may receive the mathematical truth, only the practiced and assisted eye may discern the star.

So legal argument was an appeal to reason, a search for fixed principles, not a mere profert of "modern instances" wherewith to ascertain by comparison of their bulk and number what is called the weight of authority, as if there could be ponderable authority apart from reason. Its proper instrument was the telescope rather than the kaleidoscope. It was an employment worthy of a sane mind, conducive to the growth of a strong mind, informing its reason and energizing all its powers. And there were legal giants in that golden age.

The men and women we celebrate and their associates did their thinking on lines straight, practical and fundamental. They kept their feet upon the ground. The flight of the wild pigeon interested them more deeply than the moral or political flights of aviating theorists or feather-brained flutterers. They never discussed the "dignity of labor." It would have seemed as useful and sensible to discuss the convenience or the propriety of vitality, for in their view there is little dignity among men except in labor. The man who did things, who made things, who produced things was the man who had best proved his right to be. With them dignity kept its ancient meaning of worthiness and usefulness was their measure of that worthiness. They held that it is the equal right and equal duty of every man to attain to that degree of usefulness or dignity, that measure of worthiness for which his natural. gifts, duly trained and honestly used, may fit him. 
It never occurred to their unsophisticated minds that any workingman's dignity might be enhanced by his submission to the order of a walking delegate to lessen the sum of his day's work or to debase its quality. They were concerned in the dignity of the laborer, in his individual independence, in his self mastery. And masters of themselves they became master workmen, master builders, builders of homes, of towns, of institutions and of a State whereof the workman hath no need to be ashamed.

In their minds any conflict between capital and labor was as unnatural and visionary as a conflict between the blade and the ear and the full corn in the ear. The dollar earned yesterday and saved, was capital as respectable as the dollar earned today, with the added mark of respectability that while the dollar earned proved useful industry, the dollar earned and saved proves also foresight and self denial. Of such crude and elemental sort was their political economy.

Busy men and women, compelled by the exigencies of their daily life to be busy, to husband their resources, to gather and not to seatter their physical and moral energies, they gave little time or talk to measures of general uplift and remote reform. With them, Christian civilization like charity began at home. Their consciences were preoccupied with their own shortcomings. Their hands and their heads found enough to do in bringing up their own children, in providing diligently for their own households, in the practice of all the kindly offices of good neighborhood. Mrs. Jellaby, if heard of, was only smiled at and Mrs. Pankhurst was not yet born.

Speaking irenically, not ironically, I am not sure that the pioneer mother's switch was not as far-reaching and beneficent in its influence as the Mother's Club is now. At any rate those boys, whose faculty of discrimination between good and bad had been sharpened, whose sense of duty, whose general moral sense had been awakened to activity under its application, showed themselves a very finished product of home discipline at Donelson and Shiloh and Vicksburg and on the march to the sea. 
Again I thank you for permitting me to join in commemorating these worthy' lives, these strong characters, these file leaders of a chosen people. I believe in the worship of ancestors, in guarding their foundations with a jealous and an unsleeping care, in holding fast to the faith and the wisdom of the ages, in treasuring the durable riches of the past, being persuaded that so long and only so long, as this shall be a land of memory shall it remain a land of promise.

\section{HENRY' COUNTY DISTRICT COURT.}

Mr. Editor:-The District Court for the county of Henry closed its spring term. last Saturday evening about 10 o'clock. Considerable business was transacted during the term, of which it is unnecessary to speak. There was one case, however, determined at this term, which (as it will remove and triumphantly refute some objections and erroneous opinions heretofore entertained of the citizens of this territory by a portion of our neighbors) it may be proper to lay before your numerous readers. The action was debt, founded on the fourth section of the act of Congress, approved February 12, 1793, brought by Thomas Flynt, a citizen of Boone county, Missouri, against Reuben Jay, Sr., John Fisher and Reuben Jay, Jr., to recover the sum forfeited by harboring or concealing a runaway negro or fugitive slave. The trial occupied two days. His Honor Chief Justice Mason presided-J. B. \& G. W. Teas and J. D. Learned were the counsel for the plaintiff; C. Olney, William H. Starr and H. H. Buckland for the defendants. Late on Saturday evening the jury retired under the instruction of the court, and after a few minutes' consultation returned into court a verdict for the plaintiff.

A LOOKER ON.

Mt. Pleasant, March 23, 1840.

-Iowa Territorial Gazette and Burlington Advertiser, Burlington, I. T., March 28, 1840. 
Copyright of Annals of Iowa is the property of State of Iowa, by \& through the State Historical Society of Iowa and its content may not be copied or emailed to multiple sites or posted to a listserv without the copyright holder's express written permission. However, users may print, download, or email articles for individual use. 